\title{
Health and Safety Conditions in Four Major Industrial Sectors of Pakistan from 2010 To 2015
}

\author{
Sotirios. Nik. LONGINOS*, Yahya. Muh. QADRI and Mahmut PARLAKTUNA, \\ Department of Petroleum \& Natural Gas Engineering, Middle East Technical University, Ankara, Turkey \\ *Corresponding Author: Sotirios. Nik. LONGINOS, Department of Petroleum \& Natural Gas Engineering, \\ Middle East Technical University, Ankara, Turkey
}

\begin{abstract}
Globalization can be determined as the industrialization worldwide. Although the globalization of economies has fetched economic development and new prosperity to many districts of the world, it has also brought with it an increasing safety concern. Even though, there are certain menaces to workplace health and safety, there is also a chance for the global community. The present study analyzes the statistics of the injured employed persons for four main sectors covered in Pakistan Labor Force Surveys from 2010-2015. In mining sector, the diagram of $F-N$ curve is also presented. The paper also aims to determine the reasons behind the accidents occurring in specific sectors so that suggestions can be made to improve the health and safety conditions in Pakistan
\end{abstract}

Keywords: safety, occupational accidents, injuries, Pakistan, Industrial Sectors

\section{INTRODUCTION}

Rapid technological advancements since the Industrial Revolution have contributed towards the transformation of human lives; however, the same growth has resulted in an increased risk for the safety and welfare of human beings. Occupational injuries or work accidents are considered not only a problem for the workers but also for the employer itself. In addition to endangering the lives and wellbeing of the workers, these accidents cause an increase in workplace absences and a reduction in labor productivity, resulting in an additional burden for the companies [1]. The International Labor Organization (ILO) has estimated that these occupational injuries and diseases, on average, have an economic cost of 1\%-3\% in developed and 4\% of GDP in developing countries [2]. According to the ILO, each year, approximately 2.3 million fatalities and 300 million accidents occur in the workplaces all over the world and even then, these estimates do not correctly portray the graveness of the problem [3]. This problem is more severe in developing countries of the world, where the working conditions are mostly considered to be of substandard, the health care facilities are not advanced or the workers have not been provided with sufficient training. The safety conditions greatly vary from country to country as well as from sector to sector within a single country. For example, industry divisions in less developed countries like agriculture and construction account for a higher percentage of total occupational injuries/diseases because a large part of population is employed in this sector and undertaking high risks are a part of these jobs [4].

According to the Pakistan Economic Survey 2016, Pakistan has the $10^{\text {th }}$ largest labor force in the world and almost $65 \%$ of the labor force is involved in agriculture/forestry/fishing, manufacturing and construction sectors [5].Although, agriculture is responsible for the greatest percentage of occupational injuries/diseases but construction sector is considered the most hazardous accounting for a large number of fatalities [6]. Several workers are employed by private contractors who force them to complete the projects on tight deadlines and in the process, they compromise on the protection of the labor. The Occupational Health and Safety conditions in Pakistan have been in need of an urgent revamp whether, the legislations, the implementation of laws, the data collection or the resources required. The legislations have not been updated according to the changing technologies in various industrial sectors that add to the complications. for example, the Factories Act 1934 does not apply to the enterprises employing less than ten workers and furthermore, it does not cover the agriculture sector, informal and seasonal workers. There are no standardized programs in universities offering 
higher education in OHS which makes most of the workforce untrained and illiterate in this field [7]."Centre for the Improvement of Working Conditions and Environment" is the only institute in Pakistan that provides training in OHS and this center was built with the collective collaboration of Punjab's Province Directorate of Labor Welfare, Finnish Institute of Occupational Health and ILO [8]. Moreover, very limited number of workers in the industries is covered with accidental insurance and other benefits like death grants and disablement pension. The Government of Pakistan has ratified only 36 of the ILO conventions of which 3 conventions have already been denounced [9]. With the very limited data available showing the statistical trends, effective steps cannot be taken to target the sectors which require immediate attention.

In the mining and quarrying industry of Pakistan, the working conditions have caused the deaths to become a norm rather than the result of accidents. Even if the workers manage to survive, the toxic elements that they inhale with the dust have resulted in several diseases like Tuberculosis [10].On the other hand, the manufacturing sector in Pakistan, especially the Textile industry, has also been suffering the same fate. The industry has been a major cause of ejecting waste pollutants and has also experienced various fire accidents. In spite of that, the conditions have remained in a pitiful state and the industry faces lack of fire prevention, waste disposal services and insufficient medical facilities. The complex machinery is vastly used without a proper understanding of the risks and a thorough training, which adds up to the number of accidents in the industry [11].Therefore, the understanding of the reasons behind occupational accidents is important so that steps can be taken to efficiently reduce the risk of such occurrences.

\section{OBJECTIVE AND METHODOLOGY}

In every industry division, there is a possibility of a work accident occurring, whether it is manufacturing, construction or a mining industry and in less developed countries like Pakistan, the mentioned industries account for a greater percentage of accidents. In this study, the previous data of occupational injuries/diseases between 2010 and 2015, obtained from Pakistan Bureau of Statistics, will be analyzed for 4 different sectors. The manufacturing, mining and quarrying, construction and agriculture/forestry/fisheries sectors employ the largest percentage of labor force in Pakistan and hence, are also the cause of the highest number of workplace injuries/diseases. Moreover, an attempt will be made to explain the reasons behind these injuries/diseases in each of the sectors and some suggestions will be presented for improving the health and safety culture in Pakistan.

This study contains the data collected from Labor Force Surveys, available on the website of Pakistan Bureau of Statistics, which are constantly updated every year. The percentages of occupational injuries/diseases between 2010 and 2015 for 4 aforementioned sectors were compiled and the trends were analyzed using 2010 as a base year. It also should be mentioned that for the mining sector, there were outcomes about the fatal accidents (as number of persons and not percentage) and the F-N curve results are presented from 2010 to 2015. The differences between rural and urban populations, level of education and reasons for accidents were studied in detail so that correlations could be made.

\section{RESULTS AND DISCUSSION}

This data presented in the Table 1 is part of a thorough study on OSH conditions in Pakistan which utilizes the relevant statistical data from Labour Force Surveys. This report presents data on occupational accidents and injuries taken from the last four Labour Force Surveys (2010-11, 2012-13, 2013-14 and 2014-15).

Table1. Percentage Distribution of Employed Persons who suffered Occupational Injuries/Diseases by Major Industry Divisions (Pakistan Bureau of Statistics, Labor Force Surveys)

\begin{tabular}{|c|c|c|c|c|}
\hline Industry Divisions & $\mathbf{2 0 1 0 - 2 0 1 1}$ & $\mathbf{2 0 1 2 - 2 0 1 3}$ & $\mathbf{2 0 1 3 - 2 0 1 4}$ & $\mathbf{2 0 1 4 - 2 0 1 5}$ \\
\hline Agriculture/Forestry/Fishing & 49.77 & 49.85 & 51.16 & 47.95 \\
\hline Manufacturing & 15.78 & 13.32 & 14.21 & 15.90 \\
\hline Construction & 13.10 & 15.24 & 14.14 & 16.27 \\
\hline Mining/Quarrying & 0.23 & 0.21 & 0.26 & 0.27 \\
\hline Others* & 21.12 & 22.08 & 20.23 & 19.61 \\
\hline
\end{tabular}

*Others include Community, Social and Personal Services/ Transport, Storage \& Communication /Wholesale \& Retail Trade, Restaurant \& Hotels/ Electricity, Gas \& Water/Other Industry Divisions 
It is obvious from Table 1 that the agriculture/forestry/ fishing sector is responsible for almost $50 \%$ of the occupational injuries/diseases in Pakistan. In 2010-11, the percentage was 49.77 which followed an increasing trend in the next three years. However, in the last year of the survey, the percentage declined by approximately 4\%. The manufacturing and construction sectors contain almost $30 \%$ of the occupational injuries/diseases. Especially in the first and the last year of the surveys we analyzed, the percentages for manufacturing sector are the same, while the middle years experienced continuous fluctuation. According to the last survey, the construction sector is the only sector which faced the highest percentage increase. In the mining sector, the percentage of occupational injuries/diseases have remained less than $0.5 \%$ and the trend has maintained stability over the years.

\subsection{Agriculture/Forestry/Fisheries Sector}

There are some major causes behind a very large percentage of accidents that occur in the agriculture/forestry/fishing sector. One of the major reason is that this sector employs the greatest percentage of labor force (42.88\% in 2014-15) in Pakistan and also has the biggest contribution to the GDP (20.88\% in 2014-15). Most of the labor force involved in this sector is illiterate, female and children living in the very rural areas of Pakistan. Like in the other countries of the world, this sector is not considered organized and the workforce is not covered by insurance or other disability benefits. In addition, the extreme weather conditions and poor infrastructure and health facilities also play a role in endangering the health and safety of the workers. Since, the vast population residing in these rural areas have no or limited access to education the number of people without even high school graduation is enormous. Approximately $85-86 \%$ of the workforce that suffered occupational injuries/diseases was without a higher education, indicating a strong correlation between education and prevention of these occupational injuries/diseases $[6,12,13]$.

Child Labor is also a common factor causing a high number of injuries in the agriculture /forestry/fishing sector. Since, a considerable percentage of rural and illiterate population is part of this sector, the families prefer their children to start working on the farms or boats from a very young age instead of sending them to school. These kids are neither educated nor trained enough to understand the dangers of operating the hand tools or machineries and hence, they suffer serious and at times, fatal injuries. In Pakistan, 1,601,094 children in the age bracket of 10-14 years were working in the agriculture/forestry/fishing sector which amounts to $74.72 \%$ of the total number of employed children between 10-14 years. Among the children employed in this sector, 38,695 children, which make $65.08 \%$ of total occupational injuries/diseases to children, belonged to this sector $[6,14]$.

The other reasons giving rise to the number of occupational injuries/diseases are the extreme climatic conditions that the workers are exposed to in the agriculture/forestry/fisheries sector especially those that are associated with agriculture and fisheries. The diverse terrain and climatic conditions in Pakistan makes it susceptible to natural disasters ranging from heavy floods to earthquake [15]. In the summer months, when the monsoon season prevails in Pakistan, several rivers swell up and inundate the agriculture fields destroying the crops and cattle and sweeping away the people living and working on farms. Despite large investments in the disaster control, there have been consistent occurrences of floods, resulting in a loss of dozens of lives and displacing 82000 people just in 2009 and 2008 respectively [16].Even though, the fertile land size has decreased over the years due to floods, the percentage of occupational injuries/diseases have somewhat remained steady during the 2010-2015 period. $46.4260 \%$ land was cultivated in 2015 which represents a decrease of $15.5024 \%$ cultivated land than 2014 [17].The government action revolves around the relief work rather than disaster prevention. The fishermen communities reside near the polluted sea water bear with poor sanitary conditions and at times, catch diseases from the rotten fish [18].

\subsection{Manufacturing Sector}

Manufacturing together with construction sector is the sector with approximately $15 \%$ of the total occupational injuries/diseases.Keeping in view the importance of the workers as the real backbone of industry, it is crucial to be understandable the reasons for people work in manufacturing industry have a high rate of occupational injuries/diseases. Poor working conditions and the absence of an effective work injury prevention program are crucial reasons. For example, in Sugar Industry many of the workers face musculoskeletal disorders due to heavy load lifting, lowering, carrying, pulling, and pushing in sugar mills. Another reason is that in sugar mills most of the workers who were injured; they were untrained and not dressed with the appropriate equipment such as gloves, helmet and 
uniform $[19,20]$. Another characteristic paradigm is the textile which is the major manufacturing sector. In stitching units, the use unsuitable lighting is not essential and does not prevent from eye diseases. The ventilation system in these stitching units of textile factories is not good and respiratory problems and diseases are common among the workers [21]. Massive occupational and environmental problems are being faced resulting from the production, use, storage, transport, handling and disposal of chemicals. Heat stress is also hazardous. Heat may also predetermine workers to other conditions. In high temperature conditions it is difficult to wear protective clothing such as gloves, uniforms and subsequently exposure to other hazards takes place. Generally, most of the workforce in manufacture sector is not well prepared to face the hazards due to lack in the basic infrastructure and qualified personnel for providing occupational health and safety services. [22, 23].

\subsection{Construction Sector}

Problems on occupational health and safety are commonly taking place in construction sector. Construction work was found to be a high risk occupational is even in modern societies [24, 25].According to Hong Kong Polytechnic University the major reasons are: the high rise of buildings which remains predominant among others. Many perils happen due to working at heights and with the vertical transportation of materials such as the fall of person or the fall of objects. Secondly, most construction sites are crowed, which do not have adequate storage spaces or spaces for ancillary works. The most frequent accidents include stepping on, striking against or being struck by objects. Last but not least, the construction sites are still employing people with labour intensive methods [26].Apart from the general reasons that are in power for the majority of the countries, specifically in Pakistani construction industry other important reasons are the incomplete protection equipment that is provided to the workers and the illiteracy of workers so as not to have awareness about safety measurements [27].It is obvious that construction industry covers professions such as plant and machine operators and assembler, technicians and associate professionals, and elementary occupations. Figure 1 which refers to 2014-2015 periods shows that these professionals cover almost $50 \%$ of occupational diseases/injuries [6,27].This is does not mean that all these diseases/injuries $(\%)$ come only from construction industry but it is indicative that construction industry includes all these professions.

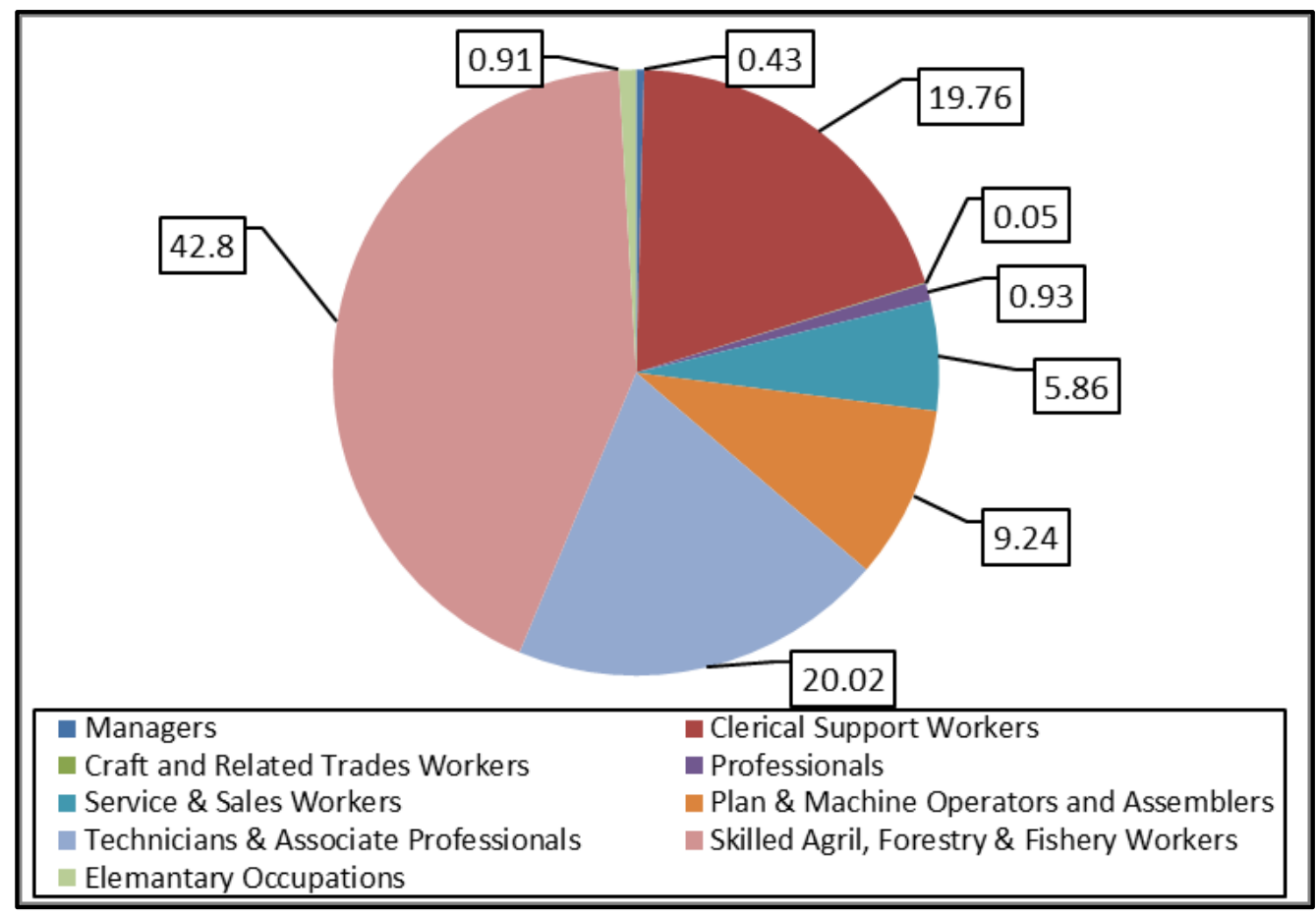

Figure1. Percentage of Occupational Diseases/Injuries by Occupation 2014-2015

Another supportive reason is the Table 2 which shows the education level. The majority of the professions that are included in construction industry (apart from engineers) do not need specific degree. It is obvious that almost $98 \%$ of diseases/injuries take place to illiterate and literate with basic knowledge and not degree persons which constitute the vast majority of people who work in construction industry. 
Table2. Distributed of Employed Persons Suffered Occupational Diseases/Injuries by Literacy and Educational Level (\%) from 2014 to 2015

\begin{tabular}{|l|c|}
\hline \multicolumn{1}{|c|}{ LEVEL OF EDUCATION } & $\mathbf{2 0 1 4 - 2 0 1 5}$ \\
\hline ILLITERATE & 49.35 \\
\hline LITERATE & 50.65 \\
\hline BELOW MATRIC & 36.09 \\
\hline MATRIC & 10.14 \\
\hline INTERMEDIATE & 2.91 \\
\hline DEGREE & 1.19 \\
\hline POST GRADUATE & 0.32 \\
\hline
\end{tabular}

\subsection{Mining \& Quarrying Sector}

The mining and quarrying sector is high risk in nature and many well published investigations into major catastrophes such as Benxihu Colliery disaster in 1942 to China with 1,549 deaths, Couriers Coal Mine disaster in 1906 to France with 1,099 deaths, Mitsubishi Hojyo Coal Mine disaster in 1914 to Japan with 687 deaths, Dhanbad Coal Mine disasters in 1965 and in 1975 to India with 375 and 372 deaths equivalently have focused the attention of both operating and contracting company management on safety issues [28].The basic causes of accidents and injuries in mines are unsafe conditions, unsafe acts, or both according to Rosen and James [29]. On the other hand, Sernia and Hwang claim that catastrophes in mine industry happens due to large mine fires, powerful mine explosions and violent rock gas detonations [30].Important accidents in mining and quarrying sector are the back injuries due to manual material-handling accidents. Restricted, ill-maintained working areas and poor visibility enhance the risk for accidents. On the contrary with safety rules most of the workers were found to work without gloves, safety boots and the appropriate uniform with the hat [31].Another significant reason for occupational injuries in Mining and Quarrying sector is the ground fall which takes place because of: 1)geological anomalies presence of faults, slips, joints and clay vein, 2)weathering effect roof deterioration due to temperature changes and moisture and 3)stress conditions- concentration and sudden release of stresses around the mine openings [32].Moreover, over exposure of gases (suffocation) and over exposure of coal dust remain also two dominant reasons for undesired consequences in mining industry [33].Last but not least in Pakistan the underground mining is implemented generally with room and pillar method of extraction which is the shabbiest and most hazardous method and this mining technique has been discarded worldwide according to Nitish and Yardarshu [34].The Figure 2 shows the deaths in Mining sector from 2011 to 2015.

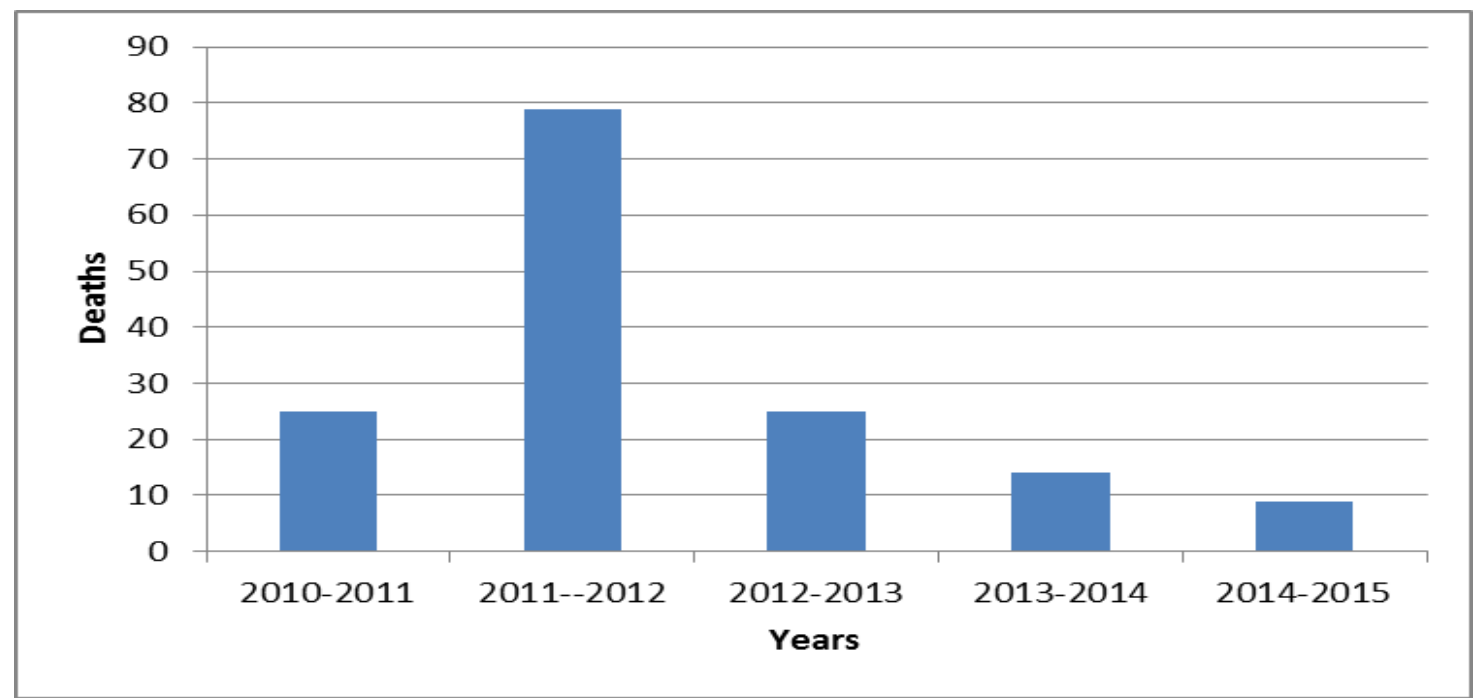

Figure2. Deaths in Mining Sector from 2011 to 2015[35]

As far as it concerns the F-N Curve, it should be mentioned that is a useful way of comparing industries. Similar curves have been developed for whole industries and activities and examples are contained in Evans book [36].FN-curves are a graphical presentation of information about the frequency of fatal accidents in a system and the distribution of the numbers of fatalities in such accidents. They plot the frequency $\mathrm{F}(\mathrm{N})$ of accidents with Nor more fatalities, where $\mathrm{N}$ ranges upward from 1 to the maximum possible number of fatalities in the system. The lower an FN-curve is located 
on the FN-graph, the safer is the system it represents, because lower FN-curves represent lower frequencies of fatal accidents than higher curves. The calculations for F-N Curve for Pakistani Mining Industry are presented in the Table 3 [37].

Table3. Fatal Accidents from 2010 to 2015 in Mining Sector

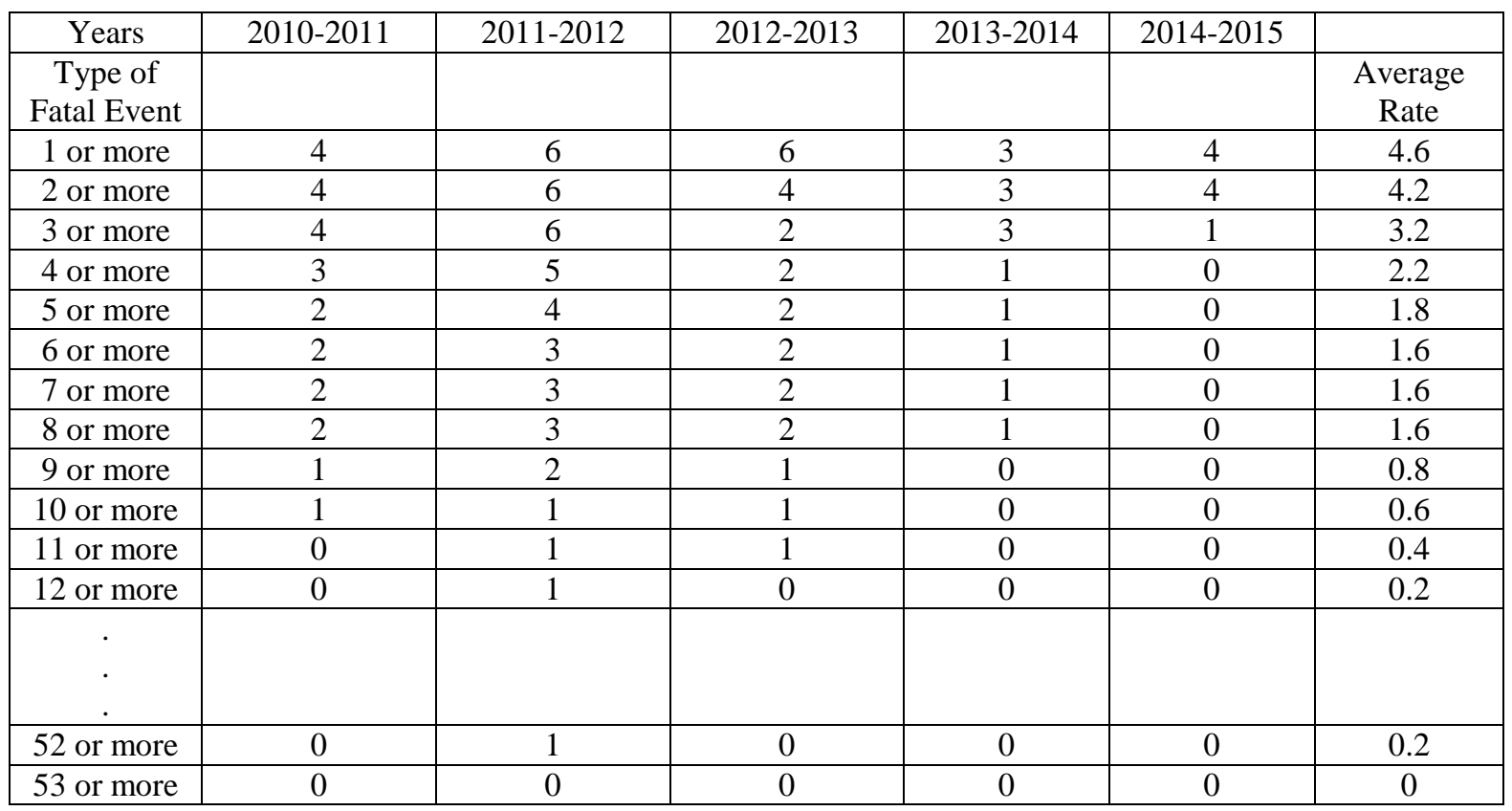

Figure3. presents the $F-N$ Curve graph for the data set of fatal accident events across the Pakistani Mining industry for the period between 2010 and 2015

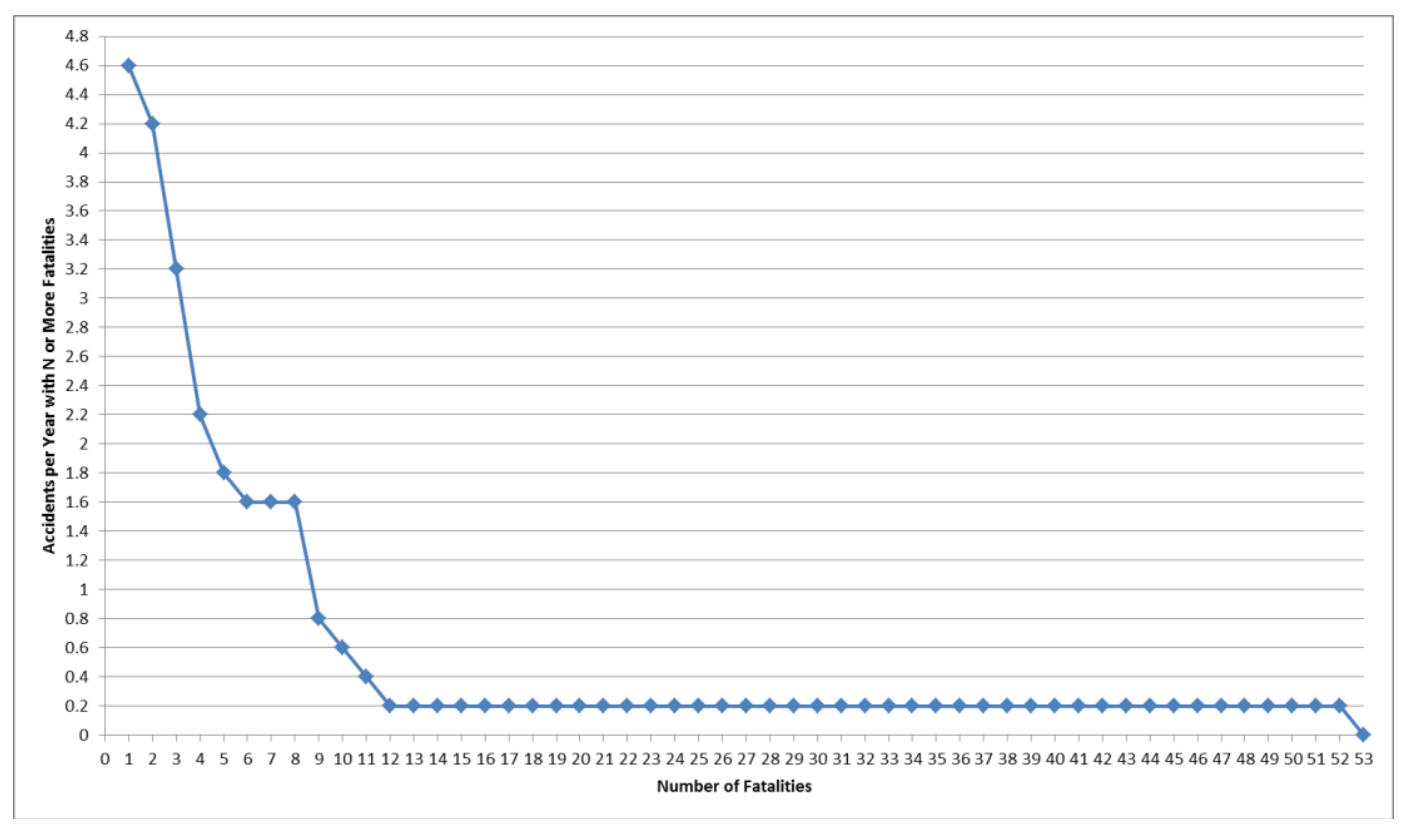

Figure3. F- N Curve for Mining Industry between 2010 and 2015

\section{EPILOGUE}

Globally there is a well-known recognition that industrial workers' conducts towards safety are affected by their perception of risk, management, safety rules and procedures. There are inherited inconveniences in fully evaluating the risks to human health. In other words, safety can be presented as algebra (has variables) and not arithmetic. For instance, there is large number of human variables such as age, race, sex, socio-economic status, education, awareness and consciousness of both employees and employers and work and environmental conditions that influence safety and occupational accidents. What is required is to weigh all the risks against the avails to guarantee a maximum margin of safety. The total cost-avail figure varies perceptibly between developed and developing countries. 
As far as it concerns the Pakistani Agricultural/Forestry/Fishery Industry the first step so as the occupational injuries to be reduced, is the ban for children below 18 years old and elder people to work and this will have success with campaign from television channels and radios. Secondly there should be a national policy about the obligatory education especial in rural areas of Pakistan and for all 4 provinces. The effectiveness of different interventions has not been evaluated. This is crucial for further ameliorations in the design of farming tool since the majority of them are hand tool. Warnings about the weather especially in summer where the monsoons prevail and anti-draining projects and controlled changes in the river's direction in case of overflow are necessary.

In manufacturing sector, the first rostrum is the mandatory traineeof the workers. The awareness of suitable clothing with uniform, gloves, boots and helmet must be a stage of the trainee for both current and future workers. To get dressed with appropriate clothes is something that the workers must start not only by themselves but also to motivate their colleagues that do not discipline to such exhortation. The trainee and the following of specific rules by the employees of these sectors will minimize the accidents. Their working environment has to do with dangerous chemicals or inappropriate conditions from the perspective of undesirable lighting and unsuitable ventilation systems as we described in our examples. Hence the amelioration of hygiene's condition and work environment will be improved by inspection of these people (Governmental Authorities) and by strict fines for companies that do not offer desirable working environments.

Construction industry was found to be a high-risk occupational area in industry. This was explained by the combination of many reasons, such as high-risk nature of construction work and limited knowledge and lack of trade risk awareness of construction workers. It is apparent that the most active manner for ameliorating safety implementation is to impede accidents before they take place. Hence, safety risk analysis is a crucial foundation upon which safety management can be amplified and risk assessment becomes important opus, which composes an integral side of safety management systems. To ameliorate safety performance of construction industry, safety professionals must ensure safety management on-site. Improving safety professionals' knowledge and awareness of safety risks will affect quality and reliability of risk assessment.

In mining and quarrying is also a sector with high-risk occupational area in industry. In controversy with safety rules workers due to no suitable education, awareness about safety and lack of training are the victims of occupational accidents. Hence Mines inspectors should strictly impose the companies to follow the safety rules. Due to the fact that the many injuries come from the old methods that are used and due to ground fall, which means lack of understanding the geological conditions, the amelioration will start from changing the room and pillar methods with safer methods such as underground, open surface (pit), placer, and in-situ mining and ensure professionals with industrial experience so as the mistakes to be avoidable. Furthermore, the frequency of back injuries will only be minimized by suitable subsistence of working places and training employees in the use of heavy load lift techniques. Generally, the workers in all industrial sectorsare the most exposed to hazardous compared to other employees. The workers in industrial sectors must be aware to get a consciousness of security and loss of life. It should not be forgotten that safety looks like algebra (has variables that every time and with different conditions change) and not geometry that following axioms or theorems can come to the solution.

\section{REFERENCES}

[1] Ceylan H. “A new approach to occupational accidents: Technique of deviation from means" Energy Education Science and Technology Part B: Social and Educational Studies 2013; 5(2):819-830

[2] International Labor Organization. "World day for safety and health at work 2009: facts on safety and health at work" [Internet]. 2009 Apr [cited 2017 Jun 17]. Available from: http://www.ilo.org/ wcmsp5 /groups/public/@dgreports/@dcomm/documents/publication/wcms_10546.

[3] International Labor Organization. “Accurate data will help to save lives” [Internet]. 2017 Apr [cited 2017 Jun 17]. Available from: http://www.ilo.org/global/about-the-ilo/how-the-ilo-works/ilo-director-general/ statements-and-speeches/WCMS_551573/lang--en/index.htm

[4] Unsar AS, Sut N. "Occupational Accidents In The Energy Sector: Analysis of Occupational Accidents That Occurred In Thermal And Hydroelectric Centrals Between 2002 And 2010 In Turkey” ProcediaSocial and Behavioral Sciences 2015; 181:388-397

[5] Pakistan Economic survey. Population, labour force and employment. Chapter 12[Internet]. 2016e16 [cited 2017 Jun 18]. Available from: http://www.finance.gov.pk/survey/chapters_16/12_Population.pdf. 
[6] International Labour Standards Unit. “Occupational Safety\&Health: Legal Framework \& Statistical Trend Analysis (2010-2015)” [Internet]. 2016 Apr [cited 2017 Jun 18]. Available from: http://ophrd. gov.pk/hrd/userfiles1/file/OSH.pdf

[7] Pasha TS, Liesivuori J. “Country Profile on Occupational Safety and Health in Pakistan” Finnish Institute of Occupational Health, Centre for the Improvement of Working Conditions and Environment Lahore Pakistan; 2003

[8] Asia Monitor Resource Centre (AMRC). “National Workshop: Occupational Safety and Health (OSH) in Pakistan” 26-27 January 2013. Lahore (Pakistan); Hotel Ambassador; 2013

[9] International Labour Organization. “Ratifications for Pakistan” [Internet]. 2016 [cited 2017 Jun 18] Available from: http://www.ilo.org/dyn/normlex/en/f?p=NORMLEXPUB:11200:0::NO::P11200_COUNTRY_ID:103166

[10] Salim A. "Mine Workers: Working and Living Conditions" Sustainable Development Policy Institute (SDPI) 2001; Working Paper Series \#62

[11] Riaz H. “Occupational, Health Safety and Environment in Textiles” [Internet]. 2010 Oct [cited 2017 Jun 18]. Available from: http://iepkarachi.org.pk/O\%20H\%20S\%20E\%20in\%20Textile---\%20Ms .\%20 Hafsa\%20Riaz.pdf

[12] Baker SP, O'Neill B, Karpf RS. The injury fact book. Lexington, MA: D.C. Health and Company, 1984.

[13] Cogbill TH, Busch Jr HM, GR, Stiers GR. Farm accidents in children. Pediatrics 1985; 76: 562-566.

[14] Kumar A, Varghese M, Mohan D. "Equipment Related Injuries in Agriculture: An International Perspective” Injury Control and Safety Promotion (2000), 7: 3,175-186

[15] Sayeeda A. Sayed, Pedro Arcos González. Flood Disaster Profile of Pakistan: A Review. Science Journal of Public Health. Vol. 2, No. 3, 2014, pp. 144-149. doi: 10.11648/j.sjph.20140203.11

[16] Oxfam's Policy Paper. Ready or Not: Pakistan's resilience to disasters one year on from the floods. 2011. Available from: http://policy practice.oxfam.org.uk/publications/ready-or-not-pakistans-resilience-todisasters-one-year-on-from-the-floods-13868

[17] Khurram Chohan ${ }^{1}{ }^{*}$, Sajid Rashid Ahmad $^{1}$, Ziaul Islam ${ }^{1}$, Muhammad Adrees ${ }^{2}$, Riverine Flood Damage Assessment of Cultivated Lands along Chenab River Using GIS and Remotely Sensed Data: A Case Study of District Hafizabad, Punjab, Pakistan, Journal of Geographic Information System, 2015, 7, 506-526

[18] Khan MN, JanjuaMY. "Improvement in Fisher Health and Safety through Poverty Alleviation: A Case Study on the Indus Basin Fishing Communities in Pakistan” Second Conference on International Fishing Industry Safety and Health 2006; 91-102

[19] Munir A, AR Tahir and MS Sabir, 2003. Optimization of milling performance of sugar plant by usinglinear programming technique. PakistanJournal Agricultural Science, 40(1-2): 87-92.

[20] Anjum Munir ${ }^{1}$, Muhammad Adeel Ashraf ${ }^{1}$, Abdul Nasir ${ }^{2}$, Oliver Hensel ${ }^{3}$ and Muhammad Iqbal" Ergonomics and Occupational Health in Sugar Industry of Pakistan"Pakistan journal of life social Sciences (2012), 10(1): 74-79

[21] Rana, I.M. 2005. Work places in industries. The daily Dawn. p.18.

[22] Ahasan, M.R. and T. Partanen. 2001. Occupational health and safety in the least developed countries-a simple case of neglect. J. Epidemiology. 11(2): 74-80.

[23] Nazia Malik ${ }^{1}$, Ashfaq Ahmed Maan1, Tariq Sultan Pasha ${ }^{2}$, Saira Akhtar1 and Tanvir Ali3, "ROLE $O F$ HAZARD CONTROL MEASURES IN OCCUPATIONAL HEALTH AND SAFETY IN THE TEXTILE INDUSTRY OF PAKISTAN”,Pak. J. Agri. Sci., Vol. 47(1), 72-76; 2010

[24] Niza, C., Silva, S., Lima, M.L., 2008. Occupational accident experience association with workers' accident explanation and definition. Safety Science 46 (4), 959-971.

[25] Liao, C.W., Perng, Y.H., 2008. Data mining for occupational injuries in the Taiwan construction industry. Safety Science 46 (7), 1091-1102.

[26] Ivan W.H. Fung,Vivian W.Y. Tam*, Tommy Y. Lo, Lori L.H. Lu,’Developing a Risk Assessment Model for construction safety", International Journal of Project Management 28 (2010) 593-600

[27] Sherif Mohamed and Tauha Ali, "Safety Behaviour in the Construction Industry in Pakistan", 4TH Triennial International Conference, Rethinking and Revitalizing Construction, Safety, Health, Environment and Quality,Port Elizabeth - South Africa,17-20 May 2005,ISBN 0-620 -33919-5,pp. 64-75

[28] Mining-Technology.com,http://www.mining-technology.com/features/feature-world-worst-coal-miningdisasters-china/

[29] S.Rosen and B.R James, 2005 "Land Degradation due to Coal extraction" American journal of environmental sciences Vol. 3-4(5); 45-56

[30] B.Sernia and Jang, M, Hwang 2007 "Coal mining dangers" International journal of occupational health, Vol. 1-5(9): 3-18. 
[31] K. J. Jadoon and J. S. Edwards, "Risk Evaluation of Lost Time Injuries in the Coal Mining Industry in Pakistan”, Journal of Engineering and Applied Science, Volume 18,No 1,January-June 1999

[32] K. J. Jadoon, J. S. Edwards and T. N. Khan, "Groundfall Accidents the Main Concern for the Coal Mining Industry in Pakistan", Journal of Engineering and Applied Science, Volume 13, No 2, July-December 1994

[33] Salahuddin Azad, Maqsood Ahmad Khan and Zarmina Akbar,"DISASTER MANAGEMENT IN COAL MINE INDUSTRY OF BALOCHISTAN", European Scientific Journal October 2015 /SPECIAL/ edition Vol.1 ISSN: 1857 - 7881 (Print) e - ISSN 1857- 7431

[34] J.S Nitish and V.P Yardarshu 2008" Impacts of mining industries in Jharkhand" Indian journal of occupational Medicines Vol. 6-3(31): 36-43.

[35] http://www.industria-union.org/sites/ default/files/ uploads/ documents/ 2016/ Pakistan/ mining_accidents _in_pakistan_2010-2016.pdf

[36] A. W. Evans. RR073-Transport fatal accidents and FN-curves: 1967-2001. Health and Safety Executive. 2003. URL www.hse.gov.uk/research/rrpdf/rr073.pdf.

[37] Transport fatal accidents and FN-curves: 1967-2001, University College London for the Health and Safety Executive 2003

\section{AUTHORS' BIOGRAPHY}

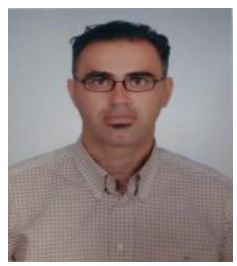

Sotirios Nik. Longinos, has a bachelor degree in Electrical Engineering from A.T.E.I. LAMIAS and Diploma (MSc Equivalent) from Chemical Engineering School of National Technical University of Athens (N.T.U.A).He continued his studies with MSc in Oil and Gas Engineering from University of Aberdeen. Now he is current $\mathrm{PhD}$ student in Petroleum and Natural Gas Engineering Department of Middle East Technical University (M.E.T.U) in Ankara. His scientific interests are Natural Gas Hydrates (Transportation-Thermodynamics-Kinetics and Production of Gas Hydrates), Well Test Analysis and Safety Engineering.

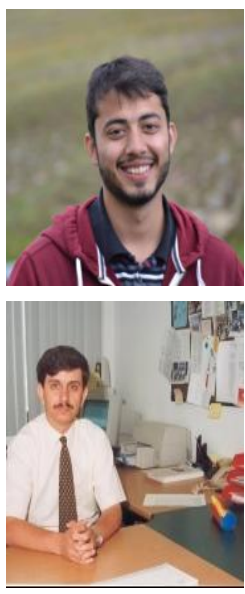

Yahya Mah. Qadri, has a bachelor degree in Petroleum and Natural Gas Engineering from Middle East Technical University (M.E.T.U) in Ankara. He works in Up Stream Energy sector of Pakistan.

Dr Mahmut Parlaktuna, has a bachelor, master and $\mathrm{PhD}$ in Petroleum and Natural Gas Engineering all of them from Middle East Technical University (M.E.T.U).He is currently Professor in the same department and he was the Director of Petroleum Research Center of Turkey, in Ankara. His scientific interests areNatural Gas Hydrates (Transportation and Storage of Natural Gas as Frozen Hydrate -Recovery of Gas from In-Situ Hydrate Reservoirs-Effect of Chemicals on Hydrate Formation (Inhibition and Promotion)), Geothermal Reservoir Engineering (Well Testing, Calcite and Silica Scaling), Hydrocarbon Phase Behaviour and Safety Engineering.

Citation: Sotirios. Nik. LONGINOS et.al, (2017). Health and Safety Conditions in Four Major Industrial Sectors of Pakistan from 2010 To 2015, International Journal of Petroleum and Petrochemical Engineering (IJPPE), 3(4), pp.102-110, DOI: http://dx.doi.org/10.20431/2454-7980.0304011

Copyright: () 2017 Sotirios. Nik. LONGINOS. This is an open-access article distributed under the terms of the Creative Commons Attribution License, which permits unrestricted use, distribution, and reproduction in any medium, provided the original author and source are credited 